\title{
Ewolucja ustawodawstwa oświatowego w Anglii w XIX i XX wieku
}

\section{WPROWADZENIE}

Anglia nie posiada konstytucji w rozumieniu kontynentalnym. Funkcjonowanie tej instytucji reguluje wiele ustaw, uchwalonych w ciągu wieków, często nawiązujących do rodzimych tradycji oraz rozmaitych precedensów. Prawne regulacje sektora edukacyjnego w Anglii uchwalane są bezpośrednio w Parlamencie Brytyjskim w Westminsterze. Oddzielna legislacja dotyczy Szkocji i Północnej Irlandii, a zajmują się tym: Szkocki Parlament i Zgromadzenie Północnej Irlandii. Systemy edukacyjne różnią się pod względem organizacyjnym, administracyjnym, nadzoru, terminologii, nominacji placówek oświatowych oraz systemu klasyfikacyjnego ${ }^{1}$. Współczesna oświata angielska zakłada, że wszystkie dzieci do 16. roku życia (edukacja obowiązkowa) i od 16 do 19 roku (edukacja nieobowiązkowa) mają jednakowe prawo do nauki i możliwość bezpłatnego dostępu do szkół. Osoby dorosłe powyżej 19. roku życia, kontynuujące kształcenie, muszą ponosić koszty związane ze zdobywaniem wiedzy. Prawną stronę oświaty regulują (analogicznie jak w wiekach XIX i XX) Education Acts - tj. ustawy edukacyjne, które stanowią podstawę legislacyjną i dotyczą zarówno Anglii, jak i Walii.

${ }^{1}$ Warto zaznaczyć, że system angielskiego prawa oświatowego, w porównaniu z polskim jest wyjątkowo skomplikowany i niełatwy do analizy. Podstawą zarówno obowiązującego polskiego prawa oświatowego, jak też pochodzącego z okresu po odzyskaniu przez Polskę niepodległości, jest lub było kilka kluczowych ustaw oraz akty prawne niższej rangi. Co oczywiste, z pewnego rodzaju wielością aktów prawnych mieliśmy do czynienia po powrocie oświaty z systemów zaborczych do systemy polskiego i po jej unifikacji, jednak nawet wówczas władze polskie nie wydawały tak znacznej ilości przepisów prawnych, jak w systemie angielskim. Co do źródeł prawa oświatowego w Polsce zob. M. Pyter, A. Balicki, Prawo oświatowe, wyd. 2, Warszawa 2015, s. 35-37. 
Podobne ustawy są również podstawą prawną dla struktur edukacyjnych w Szkocji. Ustawy edukacyjne są uzupełniane przez zarządzenia władz lokalnych².

Celem artykułu jest przedstawienie stanu angielskiej oświaty w XIX i XX w. W pracy skupiono się wyłącznie na obszarze Anglii, pomijając pozostałe części składowe Zjednoczonego Królestwa Wielkiej Brytanii i Irlandii Północnej. Powyższą cezurę wybrano z tego głównie powodu, że właśnie wspomniane stulecia przyniosły istotne zmiany w prawie oświatowym. $Z$ tego też powodu kluczowe dla angielskiej edukacji akty prawne poddano analizie. Ze względu na artykułowy charakter opracowania skupiono się jedynie na najistotniejszych aktach prawnych i najbardziej reprezentatywnych przepisach poszczególnych ustaw. Jednocześnie mając na uwadze, że problematyka angielskiego prawa oświatowego jest wyjątkowo interesująca i nadal niezbadana, uzasadnione wydaje się podjęcie dalszych poszukiwań w tym zakresie. System angielskiego prawa oświatowego zasługuje bowiem w pełni na odrębną monografię.

O lukach w badaniach przedmiotowego problemu świadczy choćby niesatysfakcjonujący stan literatury. Brakuje - głównie na rynku rodzimym - opracowań, choćby cząstkowych. Zdecydowanie lepiej zagadnienie to - co oczywiste - jest potraktowane przez uczonych brytyjskich. $Z$ tego też powodu niemal całość literatury i akty prawne wykorzystane $\mathrm{w}$ artykule, zostały zebrane podczas kwerendy przeprowadzonej w Bodleian Law Library w Oksfordzie oraz w Senate House Library w Londynie.

\section{ROZWÓJ ANGIELSKIEGO PRAWA OŚWIATOWEGO W XIX WIEKU}

Na rozwój angielskiej oświaty, rozbudowę sieci szkół i upowszechnienie dostępu do edukacji bez wątpienia wpływ miały przemiany gospodarcze i społeczne dokonujące się w całej Wielkiej Brytanii. Należy jednak pamiętać, że przez setki lat w Anglii funkcjonowały elitarne szkoły i uniwersytety, przeznaczone wyłącznie dla najzamożniejszej części społeczeństwa. Ponadto arystokracja korzystała z powszechnego wśród tej klasy społecznej nauczania domowego. Oprócz tego funkcjonowały także - co oczywiste - szkoły prowadzące nauczanie na poziomie podstawowym dla osób z innych grup społecznych, jednak było ich stosunkowo niewiele. Jako przykład można tu wymienić: Day Schools czy Sunday Schools. Wspomniane wyżej placówki były głównie zakładane bądź finansowane przez dwa stowarzyszenia - National Society for promoting the Education of the Poor in the Principles of the Established Church oraz British and Foreign School

\footnotetext{
${ }^{2}$ S. Dobrzelewski, Brytyjski system szkolny i informacja edukacyjna, $<$ http://www.bbc.uw.edu. pl/Content/41/14.pdf> [dostęp: 24.03.2015].
} 
Society $^{3}$. Głównie National Society odnosiło sukcesy w kwestii popularyzacji szkolnictwa ${ }^{4}$. Trzeba pamiętać, że szczególnie w małych miasteczkach, na wsiach czy w biedniejszych dzielnicach dużych miast dzieci i młodzież nie miały praktycznie żadnego dostępu do edukacji. Przyjmuje się, że w połowie XIX w. około 1/4 dzieci mieszkających w Anglii nie pobierało żadnej nauki, zarówno w szkole, jak też w domu ${ }^{5}$. Co więcej, biorąc pod uwagę, że na Wyspach Brytyjskich systematycznie zwiększała się liczba ludności, lawinowo rosła grupa pozbawiona dostępu do edukacji.

Przyjmuje się, że początkiem zmiany w sposobie myślenia o konieczności edukowania ludności, była postępująca na wyspach w XIX w. industrializacja przemysłu, a także szybki przyrost naturalny oraz napływ ludności do miast. O ile w 1801 r. Anglię (łącznie z Walią) zamieszkiwało niecałe 9 milionów ludzi, o tyle już 50 lat później było ich dwukrotnie więcej, a w 1901 r. 32,5 miliona ${ }^{6}$. Zaistniała naturalna potrzeba, aby państwo zadbało o stworzenie sieci szkół i żeby organy państwowe czuwały nad podejmowaniem nauki przez dzieci i młodzież. Warto dodać, że postępująca mechanizacja wymagała od klasy pracującej co najmniej znajomości czytania, pisania i rachowania. Ponadto coraz bardziej stawali się potrzebni ludzie posiadający wyższe techniczne wykształcenie - inżynierowie, chemicy, fizycy, a także handlowcy i księgowi ${ }^{7}$. Mając na uwadze fakt, że specjalistyczne wykształcenie mogło być dopiero uzupełnieniem wiedzy elementarnej, to jest podstaw języka, matematyki, geografii czy historii, należało najpierw wdrożyć podstawy edukacji. Konieczność uchwalenia pierwszego prawa, gwarantującego dostęp do oświaty na poziomie podstawowym wszystkim członkom społeczeństwa, niezależenie od posiadanego majątku uzasadniano między innymi tak: „,nasza przemysłowa własność zależy od pośpiechu z jakim weźmiemy się do wychowania ludowego. Przy niedostatku początkowego wykształcenia, wykształcenie techniczne zbytecznym zdaje się być dla naszych rzemieślników; wielka ich u nas liczba pozbawioną jest zupełnie oświaty, a zatem i wszelkiej znajomości rzeczy"s.

3 J.E. Hales, British Education, Edinburgh 1940, s. 12-13.

${ }^{4}$ G. Balfour, The Educational systems of Great Britain and Ireland, Oxford 1903, s. 4.

${ }^{5}$ Przy czym trzeba pamiętać, że są to dane uśrednione uwzględniające zarówno bogatszą część społeczeństwa (w której nauczanie było powszeche) oraz biedniejszą (w której edukacja najmłodszych należała do rzadkości). Zob. C. Jorns, The London School Board, Lübeck 1894, s. 3.

${ }^{6}$ G. Balfour, op. cit., s. 289.

7 Więcej zob. T.L. Jarman, Landmarks in the History of Education. English Education as part of the European Tradition, London 1951, s. 209-212; W.E. Marsden, Education and the Social Geography of Nineteenth-Century Towns and Cities, [w:] Urban Education in the 19th century, red.

D. Reeder, London 1977, s. 49-73; I. Morrish, Education Since 1800, London 1970, s. 3-22.

${ }^{8}$ M.C. Hippeau, Wychowanie publiczne w Anglii, thum. S. Bełza, Warszawa 1874, s. 9. 
Idąc tym tokiem rozumowania, w 1841 r. uchwalono School Sites Act ${ }^{9}$. Przepisami tej ustawy ułatwiono nabywanie ziemi w celu budowy na tych terenach obiektów szkolnych. Utworzono także dotację Parliamentary Grants for the Education of the Poor, która miała na celu zapewnienie najuboższym osobom pomoc w dostępie do edukacji. Co kilka lat nowelizowano przepisy School Sites Act 1841, znosząc kolejne bariery w podejmowaniu przez społeczeństwo nauki oraz umożliwiając w sposób niemal masowy budowę kolejnych szkół ${ }^{10}$. Następnym krokiem do upowszechnienia szkolnictwa było uchwalenie w 1855 r. School Grants Act ${ }^{11}$, w którym przewidziano, że budynki szkolne ufundowane przez Parlament dzięki dotacji (Parliamentary Grant for the Purposes of Education) mogą zostać sprzedane, zamienione bądź obciążone hipoteką tylko pod warunkiem uzyskania pisemnej zgody Secretary of State for the Home Department. Przepis ten zapobieg1 niekontrolowanemu wprowadzaniu zmian w zakresie angielskiej oświaty.

Powszechnie przyjmuje się, że pierwszym aktem dotyczącym angielskiej oświaty, który sensu stricto zapoczątkował jej reformę był Elementary Education Act z $1870 \mathrm{r}^{12}{ }^{12}$ Jednak bezsprzecznie krokiem w jego kierunku i podstawą do jego uchwalenia był opublikowany dziewięć lat wcześniej raport, przygotowany przez The Royal Commission on the State of Popular Education in England, znany też jako Newcastle Report ${ }^{13}$. W dokumencie tym po raz pierwszy szczegółowo i gruntownie opracowano zagadnienia związane $\mathrm{z}$ angielskim szkolnictwem funkcjonującym na poziomie podstawowym. W raporcie wskazano, że ponad 120 tys. dzieci nie zostało w ogóle objętych nauczaniem, tj. nie uczęszcza do szkoły, jak również nie pobiera nauki w domu. Ponadto podkreślono, że szkoły znacząco różnią się od siebie co do jakości świadczonych usług edukacyjnych, zaś jedynie niewielka część uczących się dzieci pobiera naukę na odpowiednim poziomie $^{14}$. Zarekomendowano dalsze wypłacanie dotacji z budżetu centralnego na budowę nowych szkół, podkreślono też konieczność dbania o dobry stan budynków szkolnych. Zwrócono uwagę, aby położyć nacisk na regularne uczęszczanie uczniów do szkół, a przede wszystkim w raporcie tym zaproponowano, by inspektorzy nadzorujący szkoły rzetelnie przeprowadzali kontrole i skrupulatnie

9 The School Sites Act 1841 (21st June 1841), (1841, ch. 77).

10 The School Sites Act 1844 (18th July 1844), (1844, ch. 37), The School Sites Act 1849 (28th July 1849), (1849, ch. 49), The School Sites Act 1851 (24th July 1851), (1851, ch. 24), The School Sites Act 1852 (30th June 1852), (1852, ch. 49).

${ }_{11}$ The School Grants Act 1855 (14th August 1855), (1855, ch. 131).

12 The Elementary Education Act 1870 (9th August 1870), (1870, ch. 75), [dalej: EEA 1870].

${ }_{13}$ Zob. Educational Documents, vol. II: England and Wales 1816 to the present day, ed. J.S. Malcure, ed. VI, Abingdon 2006.

14 The Royal Commission on the State of Popular Education in England [Newcastle Commission], Parliamentary Papers, 1861, XXI. s. 293-328, [w:] English Historical Documents: 18331874, red. G.M. Young, W.D. Hancock, t. XII (1), New York 1956, s. 891-897. 
przedstawiali ich wyniki, tak aby nie dochodziło do sytuacji, gdy absolwenci niektórych szkół nie potrafią dostatecznie pisać czy też płynnie czytać15.

Zasadnicze znaczenie dla wieloletniej reformy angielskiej oświaty miały jednak wspomniane już przepisy Elementary Education Act z 1870 r. Dzięki tej ustawie po raz pierwszy podzielono kraj na okręgi szkolne (school districts), w których miały funkcjonować rady szkolne (school board), będące organami administracji oświatowej w poszczególnych regionach. Okręgi szkolne w znacznej mierze terytorialnie pokrywały się z gminami (boroughs) i parafiami (civil parishes), przy czym miasto Londyn stanowiło odrębny okręg ${ }^{16}$. Wyodrębnienie okręgów szkolnych miało na celu przede wszystkim uzupełnienie sieci szkół podstawowych, gdyż rady szkolne zostały wyposażone w obowiązek dbania o odpowiednią liczbę miejsc w szkołach na obszarze swojego okręgu ${ }^{17}$. Rady miały też w swojej kompetencji możliwość zakładania nowych placówek szkolnych, modernizowania już istniejących, ale także mogły likwidować szkoły, jeśli któraś z nich stawała się zbędna $^{18}$. Te swoiste organy lokalnej administracji działające w zakresie oświaty, miały także dbać o prawidłowe funkcjonowanie szkół, co dawało im uprawnienia do decydowania o tym, czy na ich terytorium nauka w szkole ma być obligatoryjna, czy dobrowolna dla dzieci między 5. a 13. rokiem życia ${ }^{19}$. Ponadto rady szkolne mogły określać, czy w szkołach znajdujących się w ich okręgu będą się odbywały lekcje religii i na jakich zasadach ${ }^{20}$.

Mimo że Elementary Education Act z 1870 nie wprowadził darmowej nauki i mimo że rady szkolne posiadały jedynie prawo do wydania przepisów o obowiązku szkolnym w swoich okręgach, to z całą pewnością można stwierdzić, że przywołany wyżej przepis art. 74 EEA 1870 stanowił pierwszy krok w kierunku wprowadzenia powszechnego obowiązku szkolnego ${ }^{21}$. Przede wszystkim zaś ustawa z 1870 r. zapoczątkowała rozwój jeszcze niecałkowicie jednolitego, ale już ogólnoangielskiego systemu oświaty ${ }^{22}$.

Jak już zostało wspomniane, w Londynie ustanowiono odrębny okręg szkolny, który uzyskał nazwę własną School-Board of London. Takie wyodrębnienie było spowodowane szczególną dbałością o rozwój oświaty w metropoliach, a przede wszystkim w stolicy kraju. Londyńska Rada Szkolna funkcjonująca w mieście, składała się z kilkudziesięciu osób i działała poprzez specjalne komisje. Najważ-

15 Zob. I. Morrish, Education since 1800, London 1970, s. 15.

${ }_{16}$ I. Morrish, op. cit., s. 18.

17 Art. 18 EEA 1870.

18 B. Lawrence, The Administration of Education in Britain, London 1972, s. 33.

19 Art. 74 EEA 1870.

${ }^{20}$ I. Morrish, op. cit., s. 18.

${ }^{21}$ D. Gillard, Education in England: a brief history, <www.educationengland.org.uk> [dostęp: 23.02.2015].

${ }^{22}$ Por. J. E. Hales, British Education, Edinburgh 1940, s. 13. 
niejsze z nich to: Statistical Committee, która określała wymaganą w danym roku liczbę miejsc w szkołach; Works Committee, która w razie potrzeby miała za zadanie zapewnić dziecku miejsce w szkole; Bye-Laws-Committee, zajmująca się wydawaniem odpowiednich aktów prawnych odnośnie do obowiązku szkolnego; School-Management i Evening Classes Committee - zajmowały się zarządzaniem szkołami podlegającymi Londyńskiej Radzie Szkolnej; Store-Committee, zapewniająca książki i inne niezbędne do nauczania wyposażenie oraz Finance Committee, której zadaniem było zapewnienie środków finansowych niezbędnych do właściwego działania Rady Szkoły ${ }^{23}$.

Kolejne lata przynosiły nowe rozwiązania prawne w zakresie oświaty, wyraźnie ją reformując. I tak w Elementary Education Act wydanym w $1876^{24}$ (Lord Sandon's $A c t$ ) zobowiązano rodziców do przestrzegania obowiązku szkolnego dzieci. Wprowadzenie tego przepisu było spowodowane między innymi tym, że o ile rady szkolne rzeczywiście wydawały przepisy o obowiązku szkolnym na swoim terytorium na podstawie Elementary Education Act 1870, o tyle niestety problemem była jego egzekucja ${ }^{25}$. Zobowiązanie rodziców do przestrzegania tego obowiązku miało przyczynić się do szybszego i skuteczniejszego upowszechnienia edukacji w Anglii. W miejscach gdzie do tej pory nie powstały rady szkolne, utworzono specjalne komisje (school attendance committees ${ }^{26}$ ), które miały egzekwować spełnianie przez dzieci obowiązku szkolnego. Skutkiem niewypełniania wspomnianego obowiązku była kara grzywny nakładana na rodziców bądź opiekunów dziecka, albo umieszczenie go w specjalnej szkole (certified day industrial school, art. 12 EEA 1876).

Jeszcze bardziej postępowe zmiany przyniosła wydana cztery lata później ustawa, zwana Mundella's Act, to jest Elementary Education Act 188027. Przepisami tej ustawy zobowiązano samorząd terytorialny do wydawania przepisów miejscowych o obowiązku szkolnym dzieci w wieku 5-10 lat. Ponadto zgodnie $\mathrm{z}$ art. 4 EEA 1880 pod groźbą kary zakazane było zatrudnianie dziecka $\mathrm{w}$ wieku 10-13 lat. Warto dodać, że mimo dotacji pozyskiwanych z budżetu państwa nauka w szkołach publicznych wciąż była płatna. Z opłat były zwolnione jedynie dzieci pochodzące $\mathrm{z}$ wyjątkowo biednych rodzin, zaś pozostałe były zobowiązane do opłacania nauki. W obliczu ustawowego nakazu wypełniania obowiązku szkolnego pobieranie opłat za naukę od rodzin najuboższych było problematyczne, także kolejnym krokiem w upowszechnianiu oświaty w Anglii miało być zniesienie tychże opłat ${ }^{28}$. Dokonano tego w 1891 r. ustawą Elementa-

${ }^{23}$ C. Jorns, op. cit., s. 9-10.

${ }^{24}$ The Elementary Education Act 1876 (15th August 1876), (1876, ch. 79), [dalej: EEA 1876].

${ }^{25}$ C. Jorns, op. cit., s. 12.

${ }^{26}$ Dosłowne tłumaczenie: komisje do spraw uczęszczania do szkoły.

${ }^{27}$ The Elementary Education Act 1880 (26th August 1880), (1880, ch. 23), [dalej: EEA 1880].

${ }^{28}$ I. Morrish, op. cit., s. 19. 
ry Education Act $1891^{29}$. Przepisem art. 1 EEA 1891 zwolniono rodziców uczniów z jakichkolwiek opłat za naukę w publicznej szkole. Ustawa przewidywała wdrożenie dotacji przez Parlament na każde dziecko w wieku pomiędzy 3. a 15. rokiem życia, które pobierało naukę w publicznej szkole podstawowej. W szkołach nie wolno było pobierać dodatkowych opłat (art. 3 EEA 1891).

Wraz z rozwojem szkół podstawowych powstawały różnorodne ośrodki kształcące na poziomie ponadpodstawowym, jednakże brak było jednego ogólnoangielskiego aktu prawnego, który regulowałby funkcjonowanie tych szkół ${ }^{30}$. Wobec tego zaistniała potrzeba powołania specjalnej komisji, która zajęłaby się problemem szkół średnich i wypracowała pewne ogólne standardy. Dlatego też w 1894 r. utworzono The Royal Commission on Secondary Education. Komisja zarekomendowała, że szkoły, w których kształcone są najbiedniejsze dzieci w wieku powyżej 14. roku życia (tzw. third grate schools), powinny zostać przemianowane na szkoły średnie (secondary schools) i być prowadzone przez lokalne władze oświatowe (local education authorities) ${ }^{31}$. Ponadto $\mathrm{w}$ raporcie zaproponowano utworzenie centralnego organu ds. oświaty ${ }^{32}$, który przejąłby niektóre funkcje Ministerstwa Edukacji oraz Ministerstwa Nauki i Sztuki. Organ taki utworzono niedługo po ogłoszeniu raportu przez Komisję, bo już w 1899 r. na podstawie przepisu art. 1 Board of Education Act ${ }^{33}$. Board of Education miał to być organ właściwy do wszystkich spraw związanych z oświatą, zarówno z tą na poziomie podstawowym, jak i tą na poziomie średnim. Między innymi został on uprawniony do przeprowadzania kontroli w szkołach oferujących kształcenie na poziomie średnim (art. 3 BEA 1899) $)^{34}$.

\section{ORGANIZACJA OŚWIATY W ANGLII W XX WIEKU}

Zalecenia Królewskiej Komisji do spraw Szkolnictwa Średniego odnośnie do szkolnictwa średniego per se po raz pierwszy wzięto pod uwagę podczas uchwalania Education Act w 1902 r. ${ }^{35}$ Zgodnie z art. 6 EA 1902 wszystkie public elementary schools miały posiadać własny zarząd. Liczebność i skład zarządu szkoły

${ }^{29}$ The Elementary Education Act 1891 (5th August 1891), (1891, ch. 56), [dalej: EEA 1891].

${ }^{30}$ Więcej na ten temat zob. I. Morrish, op. cit., s. 41-46.

${ }^{31}$ Dosłowne tłumaczenie: lokalne władze oświatowe. Pojęcia local education authority używa się po dziś dzień zarówno w ustawodawstwie, orzecznictwie, jak i literaturze przedmiotu na oznaczenie tych władz lokalnych, które są wyposażone w odpowiednie kompetencje oświatowe, zob. K.P. Pool, J.E. Coleman, P. M. Liell, Butterworths Education Law, London-Edinburgh-Dublin 1997, s. $13-18$.

32 I. Morrish, op. cit., s. 47-48.

33 The Board of Education Act 1899 (9th August 1899), (1899, ch. 33), [dalej: BEA 1899].

${ }^{34}$ Więcej na temat Board of Education zob. J.E. Hales, British Education, s. 15-16.

35 The Education Act 1902 (18th December 1902), (1902, ch. 42), [dalej: EA 1902]. 
różnił się w zależności od tego, czy szkoła była prowadzona przez lokalne władze oświatowe, czy też przez inny podmiot. Niezależnie zaś od tego, kto był organem prowadzącym, w składzie zarządu musiało zasiadać przynajmniej dwóch przedstawicieli władz lokalnych.

Na mocy wspomnianego aktu odpowiedzialność za skuteczną i efektywną działalność szkolnictwa na danym obszarze przeniesiono na local education authorities. $\mathrm{Z}$ jednej strony na większe lokalne władze oświatowe, tj. właściwe rady hrabstw (county councils) i rady gmin (county borough councils) oraz z drugiej strony na mniejsze lokalne władze oświatowe, czyli rady gmin miejskich o ponad 10 tysiącach mieszkańców (municipal boroughs councils) oraz rady dystryktów miejskich o ponad 20 tysiącach mieszkańców (urban districts councils), (art. 1 EA 1902). Ten decentralizacyjny zabieg spowodował uzyskanie przez władze lokalne wszystkich praw, jakie do tej pory przysługiwały Radom Szkolnym (art. 1 EA 1902). Trzeba wspomnieć, że ze względu na fakt, iż obie grupy władz lokalnych wyposażone zostały w takie same zadania oświatowe, prowadziło to niejednokrotnie do wielu sporów kompetencyjnych pomiędzy nimi ${ }^{36}$.

Przepisami Education (Provision of Meals) Act $1906^{37}$ uprawniono local education authorities do zapewnienia w prowadzonych przez siebie szkołach posiłków oraz finansowania posiłków dla dzieci niedożywionych. Zabieg ten dotyczył szkół podstawowych. Rok później - 28 sierpnia 1907 uchwalono Education (Administrative Provisions) $A c t^{38}$. Ustawa ta dała początek przepisom dotyczącym opieki medycznej nad dziećmi uczęszczającymi do szkoły.

Nie ulega wątpliwości, że wpływ na relacje społeczne, w tym także na szkolnictwo i oświatę miała I wojna światowa. Podobnie jak w większości Europy, swoje tragiczne żniwo zebrała także w Wielkiej Brytanii, a co za tym idzie w Anglii. Ogromne rzesze ludności zostały wcielone do wojska, wiele osób straciło życie, a ogromna liczba żołnierzy powróciła z frontu ranna. Ludność dziesiątkował tyfus, malaria i grypa. Mimo że ówczesny premier Lloyd George starał się wprowadzać reformy w różnych dziedzinach życia, to wydatki publiczne związane z ogólnie trudną sytuacją nie sprzyjały temu przedsięwzięciu. Lata powojenne okazały się niełatwe w wielu dziedzinach życia. Ponownie okres stagnacji dotknął również obszar angielskiej oświaty. Globalny kryzys, przesilenia polityczne, załamanie przemysłu, ogromne bezrobocie sprowadzały reformy edukacyjne i rozwój oświaty na dalsze plany ${ }^{39}$.

36 R. Armfelt, The Structure of English Education, London 1955, s. 43-47.

37 The Education (Provision of Meals) Act 1906 (21st December 1906), (1906, ch. 57).

${ }^{38}$ The Education (Administrative Provisions) Act (28 August 1907), (1907, ch. 43).

39 Co do szczegółów zob.: H.W. Richardson, The Economic Significance of the Depression in Britain, ,Journal of Contemporary History” 4 (1970), nr 4, s. 3-19. 
Pierwszą ustawą, która na nowo rozpoczęła zachwianą w czasie wojny reformę angielskiej edukacji, był akt wydany w 1918 r. - Education Act $1918^{40}$. Jego głównym założeniem było podniesienie górnej granicy spełniania obowiązku szkolnego do 14. roku życia (art. 8 EA 1918). Młodzież do 16. roku życia była zobowiązana do uczęszczania na dodatkowe lekcje i kursy, w wymiarze 320 godzin rocznie zgodnie z programem ustalonym przez właściwe local education authority. Niewypełnianie tego swoistego obowiązku nauki wiązało się z karą grzywny nakładaną na rodziców bądź opiekunów ucznia W wysokości od 25 pensów do 5 funtów (art. 10-11 EA 1918). W publicznych szkołach podstawowych ostatecznie zniesiono opłaty za naukę, z wyłączeniem opłat ustanawianych na podstawie przepisów Education (Provision of Meals) Act 1906 i Local Education Authorities (Medical Treatment) Act 1909 (art. 26 EA 1918).

Od 1923 r. Komisja Konsultacyjna Rządu (The Government's Consultative Committee) rozpoczęła konsolidację przepisów odnoszących się do angielskiej oświaty. Wydanych zostało kilka raportów, które ostatecznie aktem z 1944 r. ${ }^{41}$ zakończyły długotrwałą reformę angielskiej edukacji. I tak, kolejne rozszerzenie obowiązku szkolnego nastąpiło w $1936 \mathrm{r}^{42} \mathrm{~W}$ art. 1-7 EA 1936 ustalono, że dzieci powinny kończyć edukację w wieku 15, a nie 14 lat. Podkreślenia wymaga jednak fakt, iż nowe przepisy nie miały obligatoryjnego charakteru, gdyż local education authorities zostały wyposażone w prawo wydawania specjalnych zaświadczeń zezwalających 15-latkom na podjęcie pracy. W $1943 \mathrm{r}$. rząd wydał White Paper: Educational Reconstruction ${ }^{43}$. W dokumencie tym zarekomendowano, by obowiązek szkolny bez żadnych wyjątków trwał do ukończenia 15. roku życia, a jeśli okoliczności pozwolą, żeby wydłużyć go o jeszcze jeden rok ${ }^{44}$.

Zanim jednak uchwalono Education Act 1944, który miał ujednolicić i uporządkować cały system oświaty, Board of Education wydało siedem raportów odnośnie do stanu szkolnictwa w Anglii. Pierwsze sześć raportów opublikowano w latach 1923-1933. Nazywane są raportami Hadowa od nazwiska sir Williama Henry'ego Hadowa, jednego z najwybitniejszych reformatorów angielskiej oświaty w początkach XX wieku. Są to: The Differentiation of the Curriculum (1923); Psychological Tests of Educable Capacity (1924); The Education of

40 The Education Act 1918 (8th August 1918), (1918, ch. 39), [dalej: EA 1918].

${ }^{41}$ The Education Act 1944 (3rd August 1944), (1944, ch. 31), [dalej: EA 1944].

42 The Education Act 1936 (31st July 1936), (1936, ch. 41), [dalej: EA 1936].

${ }^{43}$ Board of Education, White Paper: Educational Reconstrucction, London 1943, <http://www. educationengland.org.uk/documents/wp1943/educational-reconstruction.html $>$ [dostęp: 18.03.2015].

${ }^{44}$ Chodziło przede wszystkim o trwającą od czterech lat wojnę. Działania na froncie miały bezpośredni wpływ na spowolnienie przemian w angielskiej oświacie. I. Morrish, op. cit., s. 59. 
the Adolescent (1926); Books in Public Elementary Schools (1928); The Primary School (1931); Infant and Nursery Schools (1933) ${ }^{45}$.

Spośród tych raportów warto wyodrębnić ten z 1926 r. - The Education of the Adolescent, w którym stwierdzono, że „wskazane jest, aby edukację dzieci w wieku do 11 lat nazywać edukacją na poziomie podstawowym, zaś edukację dzieci w wieku powyżej 11 lat - edukacją na poziomie średnim" ${ }^{\text {"4 }}$. Zatem tym aktem zaproponowano jednoznaczne rozgraniczenie szkolnictwa na poziomie podstawowym (primary education) od szkolnictwa na poziomie średnim (secondary education, post-primary education).

Niewątpliwie jednak najważniejszym z raportów Hadowa był dokument o tytule The Primary School. Poruszono w nim między innymi kwestię liczebności klas w szkołach podstawowych. Podkreślono, że im mniejsze będą te klasy, tym efektywniejsza będzie nauka. Zarekomendowano, aby klasy w szkołach podstawowych nie miały więcej niż 35 uczniów. Ponadto uznano, że potrzebne jest rozdzielanie chłopców i dziewcząt na lekcjach wychowania fizycznego. Podkreślono również, żeby dla dzieci opóźnionych w rozwoju tworzyć odrębne, niewielkie klasy ${ }^{47}$.

W pochodzącym z 1938 r. raporcie The Consultative Committee on Secondary Education with Special Reference to Grammar Schools and Technical High Schools, zwanym w literaturze raportem Spensa, przedstawiono blisko 170 propozycji zmian w szkolnictwie angielskim. Między innymi zarekomendowano wprowadzenie trzech typów szkół średnich: grammar schools (dla najzdolniejszych uczniów), technical schools (prowadzących kształcenie głównie w zakresie przedmiotów ścisłych) i modern schools (dla pozostałych). Dzieci kończące naukę na poziomie podstawowym miałyby wybrać określoną ścieżkę edukacyjną, najbliższą ich zainteresowaniom lub zdolnościom ${ }^{48}$.

Podobnie jak I wojna światowa wpłynęła negatywnie na rozwój angielskiej oświaty, tak też II wojna w zakresie rozwoju edukacji stanowiła widoczną przeszkodę. Dopiero wejście w życie Education Act 1944 umożliwiło unifikację przepisów w angielskim systemie oświaty. Uregulowano sprawy centralnej i lokalnej administracji oświatowej, w tym podział zadań pomiędzy Ministerstwo Eduka-

${ }^{45}$ B. Lawrence, The Administration of Education in Britain, s. 53-58; D. Gillard, Education in England: a brief history, szczegółowe dane na temat raportów Hadow'a znajdują się na stronie internetowej: <http://www.educationengland.org.uk/articles/24hadow.html> [dostęp: 11.03.2015].

${ }^{46}$ Board of Education, The Education of the Adolescent (H.M.S.O., 1927), s. 95, cyt. za: I. Morrish, op. cit., s. 29, [tłum. E. Czepczyńska].

${ }^{47}$ I. Morrish, op. cit., s. 30.

${ }^{48}$ Board Of Education, Report of The Consultative Committee on Secondary Education with Special Reference to Grammar Schools and Technical High Schools, London 1938, <http://www. educationengland.org.uk/documents/spens/spens1938.html> [dostęp: 1.03.2015]. 
cji a local education authorities. Podzielono realizację obowiązku szkolnego na trzy etapy edukacyjne - edukację podstawową (primary education), średnią (secondary education) i dalszą (further education). Zakazano prowadzenia szkół podstawowych i średnich w jednym budynku szkolnym, tak aby oddzielić małe dzieci w wieku 5-10 lat od 15- czy 16-latków. Ponadto w nowej ustawie poruszono zagadnienie szkolnictwa prywatnego, kwestię finansowania oświaty oraz inne problemy, ustanowiwszy tym samym całkiem nowy porządek w angielskim szkolnictwie.

Ponadto wprowadzono urząd Ministra Edukacji, który miał być powoływany przez króla i miał sprawować nadzór nad oświatą w całym państwie. Głównym zadaniem ministra miało być rozpowszechnianie idei edukacji wśród obywateli, dbanie o rozwój szkół i innych placówek oświatowych, a także wyznaczanie kierunku działania w zakresie szkolnictwa samorządom terytorialnym oraz sprawowanie nad nimi kontroli (art. 1 EA 1944).

Przepisami przywoływanej ustawy zmniejszono liczbę local education authorities, gdyż charakter lokalnych władz oświatowych stał się przymiotem jedynie rad hrabstw (county council) i rad gmin (county borough council), wykluczywszy $\mathrm{z}$ tego grona rady gmin miejskich i rady dystryktów miejskich (municipal borough councils oraz urban district councils). Zgodnie z art. 8 ust. 1 EA 1944 local education authorities zostały zobowiązane do zapewnienia wszystkim dzieciom zamieszkałym na obszarze danej jednostki równego dostępu do szkół podstawowych i średnich. Aby zadośćuczynić temu obowiązkowi local education authorities miały możliwość zakładania i prowadzenia nowych szkół. Mogły także prowadzić szkoły założone przez inne podmioty lub jedynie partycypować w prowadzeniu tego typu placówek (art. 9 EA 1944). W zależności od tego, kto założył daną szkołę, dzieliły się one na county i voluntary schools. Pierwsze z nich były to jednostki zakładane przez local education authorities, drugie natomiast przez inne podmioty. Voluntary schools dzieliły się na dwa typy: voluntary aided i voluntary controlled, ze względu na rodzaj pomocy finansowej otrzymywanej od państwa. Zgodnie z art. 15 EA 1944 przydomek aided otrzymywały te szkoły, które były w stanie finansować samodzielnie co najmniej 50\% swojej działalności, zaś controlled - te szkoły, które nie były w stanie pokrywać choćby połowy swoich wydatków. Pozostałą część pieniędzy na pokrycie kosztów działalności szkoły otrzymywały z budżetu państwa ${ }^{49}$.

Zgodnie z art. 35 i 36 EA 1944 obowiązek szkolny obejmował dzieci w wieku 5-15 lat, a za jego wypełnianie odpowiedzialni byli rodzice, którzy podlegali kontroli przez local education authorities. Nieprzestrzeganie obowiązku szkol-

${ }^{49}$ K. Kotłowski, Szkoła angielska po drugiej wojnie światowej, Warszawa 1960, s. 54-55; B. Lawrence, The Administration of Education ..., s. 67-68. 
nego stanowiło wykroczenie zagrożone karą grzywny lub pozbawienia wolności (art. 40 EA 1944). Ustawa wprowadzała szczegółowe przepisy dotyczące opieki lekarskiej dla uczniów, odżywiania ich w szkole oraz dbałości o ich dobrą kondycję fizyczną (art. 48-57 EA 1944).

Artykuły 70-75 EA 1944 dotyczyły kwestii independent schools. Po pierwsze Ministry of Education ustanowiono organem rejestracyjnym dla wszystkich independent schools. Przepisy tej ustawy wprowadzały kary grzywny dla osób prowadzących szkoły prywatne bez właściwego wpisu do rejestru, a także określały procedurę skarżenia independent schools w kilku przypadkach, w tym $\mathrm{m}$. in. gdy budynki szkolne nie nadawały się do prowadzenia działalności oświatowej. Postępowanie wszczynał właściwy minister, wysyłając do organu prowadzącego szkołę notice of complain z zakreślonym terminem na dokonanie odpowiednich zmian w placówce lub wniesienie odwołania do Independent Schools Tribunal.

Warto zaznaczyć, że mimo optymalnych rozwiązań zastosowanych w przytaczanej ustawie, nie zawierała ona kompleksowych rozwiązań dotyczących jednego z rodzajów szkół, jakim były secondary schools. Art. 8 EA 1944 zalecał jedynie, aby szkoła była dostosowana do wieku i możliwości uczniów. Wywnioskowano jednak z tak ogólnego przepisu, że secondary schools, aby mogły spełniać swoją rolę powinny funkcjonować w trzech różnych wersjach. Każdy z typów szkoły średniej miał być właściwy dla innej grupy uczniów: grammar schools dla najzdolniejszej młodzieży, secondary technical schools dla osób zainteresowanych przedmiotami ścisłymi i secondary modern schools - dla pozostałych uczniów. W rzeczywistości jednak system angielskiego szkolnictwa średniego nie miał charakteru trójdzielnego, a jedynie dwuczęściowy, gdyż utworzenie i prowadzenie szkoły technicznej wymagało dużych nakładów finansowych, co w powojennej Anglii stanowiło istotny problem ${ }^{50}$.

Education Act 1944 był odzwierciedleniem panujących w szkołach angielskich stosunków, częściowo zakorzenionych jeszcze w XIX wieku. Naród angielski wysoko ceniący sobie tradycję i panujące zwyczaje, niechętnie przystał na tak postępowe zmiany w panującym porządku prawny ${ }^{51}$. Nieżyjący już teoretyk i filozof wychowania twierdził, że „Education Act 1944 nie jest aktem rewolucyjnym, lecz wynikiem poszukiwania przez warstwy rządzące kompromisu pomię-

${ }^{50}$ D. Gillard, Education in England: a brief history oraz National Association of Labour Teachers, The Comprehensive School: Its History and Character, 1948, s. 7-16, [w:] W. van der Eyken, Education, the Child and Society. A documentary history 1900-1973, London 1973, s. 404-413.

${ }^{51}$ Więcej na temat przyczyn uchwalenia Education Act 1944 oraz charakteru tej ustawy i rozwiązań prawnych w niej przyjętych zob. G. McCulloch, Educational Reconstruction: The 1944 Education Act and the Twenty-first Century, Abingdon 2011; R. Cocks, Ram, Rab and the civil servants: a lawyer and the making of the 'Great Education Act 1944', „Legal Studies” 21 (2001), Issue 1, s. 15-35. 
dzy różnymi sprzecznymi siłami działającymi w społeczeństwie. Akt w zasadzie niczego w dotychczasowym szkolnictwie nie burzy i unika ścisłych sprecyzowań, stwarzając bardzo szerokie ramy dla reform. Ustawy o szkolnictwie w Wielkiej Brytanii ukazują się na ogół wtedy, gdy życie opracuje już i wykrystalizuje pewien fragment rzeczywistości szkolnej" ${ }^{2}$.

Wbrew tej opinii uzasadnione wydaje się twierdzenie, że Education Act 1944 można jednak uznać za pierwszy akt prawny mający charakter progresywny w stosunku do aktów poprzednich. Nie da się zaprzeczyć, że uchwalenie tejże ustawy miało niebagatelny wpływ na system oświaty, na funkcjonowanie szkół i na rozwój edukacji, choć trzeba mieć wzgląd także na to, że w ustawie z 1944 r. dokonano jedynie swoistej rekapitulacji dotychczasowych osiągnięć w dziedzinie angielskiego prawa oświatowego. Zebrano $\mathrm{w}$ jeden dokument wszystkie dotychczas opracowane i sprawdzone normy oraz zasady i stworzono pierwszy traktujący kompleksowo system edukacji akt prawny. Następna tak doniosła reforma szkolnictwa w Anglii zostanie przeprowadzona dopiero po przeszło 50 latach w 1996 r. uchwaleniem Education Act $1996^{53}$.

\section{PODSUMOWANIE}

Opracowanie zagadnienia dotyczącego prawa oświatowego w Anglii nie należy do łatwych. Nawet jeśli za przedmiot eksploracji weźmiemy edukację tylko w wybranym okresie. Wpływ na to ma struktura angielskiej oświaty, jak też wielość aktów prawnych różnej rangi odnoszących się do edukacji.

Szczególny okres dla rozwoju angielskiej oświaty nastąpił w XIX i XX w. Było to związane głównie $\mathrm{z}$ dziewiętnastowiecznym rozwojem gospodarczym i społecznym Anglii, zwłaszcza zaś z jej uprzemysłowieniem. Potrzeba posiadania wykwalifikowanych pracowników, pociągnęła za sobą rozrost szkolnictwa na wszystkich poziomach. Siłą rzeczy nie mogło się to jednak obyć bez regulacji prawnych dotyczących oświaty. Analogicznie, zwiększająca się stale liczba ludności na Wyspach Brytyjskich (także w Anglii) powodowała, że należało zadbać o rozwój ludności. Rozpoczęto zatem unifikację ale także rozbudowę szkolnictwa.

Wiek XIX i XX okazał się dla angielskiego prawa oświatowego okresem wzmożonego wydawania przepisów prawnych. Najczęściej problematyka ta była regulowana za pomocą różnego rodzaju Education Acts, choć trzeba wskazać także akty prawne innej rangi. Analiza przepisów pozwala na stwierdzenie, że dużym problemem, który był wielokrotnie regulowany przez ustawy, była odpłatność za pobieranie nauki oraz spełnianie obowiązku szkolnego i jego egzekucja. Można

\footnotetext{
${ }^{52}$ K. Kotłowski, op. cit., s. 41.

53 The Education Act 1996, (24th July 1996), (1996, ch. 56).
} 
założyć, że wynikało to głównie ze wspomnianego wyżej braku stabilizacji społeczeństwa angielskiego, ale też jego ciągłego rozwoju. Istotne także jst to, że uprzemysłowienie bezpośrednio wpłynęło na utworzenie kilku rodzajów szkół, przeznaczonych dla nauczania poszczególnych zawodów. Ustawodawca angielski zajął się także zagadnieniami pobocznymi, choć bardzo ważnymi z punktu widzenia ucznia. Trzeba tu wymienić opiekę medyczną czy dożywianie dzieci w szkołach.

Warto zwrócić uwagę, że działania wojenne - zarówno pierwszej, jak też drugiej wojny - zahamowały rozwój ustawodawstwa dotyczącego prawa oświatowego w Anglii. Jednak pomijając okresy ustawodawczego regresu spowodowanego działaniami wojennymi, należy podkreślić wyjątkowo dynamiczny rozwój angielskiego prawa oświatowego. Można nawet odnieść wrażenie, że stanowi ono nagromadzenie zawiłych i nadmiernie rozbudowanych przepisów prawnych. W ocenie autorów artykułu był to zabieg niezbędny i ostatecznie powodujący logiczne i klarowne wkomponowanie systemu oświaty w strukturę społeczną Anglii.

\section{THE EVOLUTION OF EDUCATION LEGISLATION IN ENGLAND IN THE $19^{\text {TH }}$ AND IN THE $20^{\text {TH }}$ CENTURY}

\section{Summary}

The issues raised in the article concern the development of education law in England from the enactment of the School Sites Act of 1841 to the enactment of the Education Act of 1944 which was the first comprehensive education act in England. Firstly, the article presents the reasons behind the rapid development of English education in the second half of the $19^{\text {th }}$ century. Furthermore, the paper delineates the influence of the economy and of the industrialization on the systematic dissemination of education. Particular attention was paid to the spread of education to the masses at the primary level and to the education of the poorest people. The article presents the successively enacted legislative acts and legislative work conducted on them in various types of committees (royal committees, government committees). Also, the results of the work of these committees is discussed, i.e. the reports prepared by the said committees which later were the basis of legislative acts.

\section{L'EVOLUTION DE LA LEGISLATION EDUCATIVE EN ANGLETERRE AU XIX'E ET XXE SIECLES}

\section{Résumé}

Le présent article aborde des questions concernant le développement de la législation éducative en Angleterre, depuis l'adoption, en 1841, de School Sites Act jusqu'à l'adoption, en 1944, de «Education Act » qui constitue la première loi exhaustive sur l'éducation en Angleterre. D'abord, l'article présente les raisons du développement rapide de 
l'enseignement anglais dans la seconde moitié du XIX ${ }^{\mathrm{e}}$ siècle, l'impact de l'économie et de l'industrialisation sur la popularisation systématique de l'éducation. En particulier, l'auteur souligne la massification de l'éducation au niveau primaire et l'accès à l'école des gens les plus pauvres. L'article présente des actes juridiques adoptés successivement, ainsi que les débats législatifs sur ces sujets dans toutes sortes de comités (commissions royales, commissions gouvernementales) et les résultats de leurs travaux, à savoir, les rapports sur la base desquels ont été créés des actes ultérieurs. 
